\title{
Isolation and Identification of Soil Bacteria from Extreme Environments of Chile and Their Plant Beneficial Characteristics
}

\author{
Alexis Gaete ${ }^{1,2,3}$, Dinka Mandakovic ${ }^{4,5}$ and Mauricio González ${ }^{1,2, *}$ \\ 1 Laboratorio de Bioinformática y Expresión Génica, Instituto de Nutrición y Tecnología de los Alimentos, \\ Universidad de Chile, El Libano 5524, 7810000 Santiago, Chile; alex.ignacio@live.com \\ 2 Center for Genome Regulation, El Libano 5524, 7810000 Santiago, Chile \\ 3 Programa de Doctorado en Ciencias Silvoagropecuarias y Veterinarias, Campus Sur Universidad de Chile. \\ Santa Rosa 11315, 8820808 Santiago, Chile \\ 4 GEMA Center for Genomics, Ecology and Environment, Universidad Mayor, Camino La Pirámide 5750, \\ 8320000 Santiago, Chile; dinka_slavja@hotmail.com \\ 5 Laboratorio de Genómica y Genética de Interacciones Biológicas (LG² IB). Instituto de Nutrición y Tecnología \\ de los Alimento, Universidad de Chile. El Líbano 5524, 7810000 Santiago, Chile \\ * Correspondence: mgonzale@inta.uchile.cl
}

Received: 29 June 2020; Accepted: 2 August 2020; Published: 10 August 2020

\begin{abstract}
The isolation of soil bacteria from extreme environments represents a major challenge, but also an opportunity to characterize the metabolic potential of soil bacteria that could promote the growth of plants inhabiting these harsh conditions. The aim of this study was to isolate and identify bacteria from two Chilean desert environments and characterize the beneficial traits for plants through a biochemical approach. By means of different culture strategies, we obtained 39 bacterial soil isolates from the Coppermine Peninsula (Antarctica) and 32 from Lejía Lake shore soil (Atacama Desert). The results obtained from the taxonomic classification and phylogenetic analysis based on $16 \mathrm{~S}$ rDNA sequences indicated that the isolates belonged to four phyla (Proteobacteria, Actinobacteria, Firmicutes, and Bacteroidetes), and that the most represented genus at both sites was Pseudomonas. Regarding biochemical characterization, all strains displayed in vitro PGP capabilities, but these were in different proportions that grouped them according to their site of origin. This study contributes with microbial isolates from natural extreme environments with biotechnological potentials in improving plant growth under cold stress.
\end{abstract}

Keywords: extreme environments; bacterial isolates; plant growth promoting bacteria

\section{Introduction}

By definition, extreme environments meet conditions that represent a difficult life opportunity for any species [1]. The geography of Chile has many ecosystems that represent complex and extreme conditions in terms of salinity, humidity, $\mathrm{UV}$ radiation, temperature, $\mathrm{pH}$, and heavy metals [2]. These conditions exert a selection pressure on the biodiversity of species, including microorganisms, which have evolved rapidly in these environments [3]. Two of the most extreme environments on Earth found in Chile include the Atacama Desert and Antarctica, which stand out for their extreme and fluctuating environmental conditions [4-7]. Antarctica is considered one of the most extreme sites in the world [8]. Here, the colonization of species and life is at its limit, not only because of the extreme low temperature and limited and sporadic availability of water, but also due to the constant cycles of freezing and thawing, continuous strong winds, and high UV radiation [9]. However, effects produced by deglaciation and climate change have allowed the colonization of plant species in soils that were 
previously covered by ice or snow [10-12]. Remarkably, plant species have managed to overcome these extreme environments and have been able to colonize and establish in these harsh scenarios. In fact, in the Coppermine Peninsula (Robert Island, Antarctic Peninsula), the Antarctic grass (Deschampsia antarctica) and the Antarctic carnation (Colobanthus quitensis) have been able to germinate and develop despite the extreme low temperature [13]. We believe that this has also produced an effect on the microbiological composition of the soil. On the other hand, the Atacama Desert is considered a cold and arid desert [14], but it presents important temperature fluctuations between day and night [5], which are even more significant in the highlands, where Lejía Lake is located. Here, it is possible to find native plant species such as Calamagrostis crispa, Nassella nardoides, and Jarava frigida $[15,16]$ at an altitude of between 4000 and 4500 meters above sea level, which is attributed to the higher levels of precipitation and humidity in the area during the summer [15]. Studying how metabolic capacities of microorganisms are influenced by cold deserts, would help us understand how these microorganisms support different processes at the ecosystem level and develop new or better biotechnological tools based on bacteria [17].

Bacteria with the capacity to contribute to plant tolerance to different environmental vicissitudes have been described in extreme environments [18]. These bacteria are defined as Plant Growth Promoting (PGP) and are related to the physiological modifications of the plant that allow them to better manage the harsh environments through the exogenous production of auxin, stimulating the elongation of adventitious roots or through the 1-aminocyclopropane-1-carboxylic acid (ACC) deaminase activity, which intervenes in the production of ethylene, inhibiting the response to senescence. Other mechanisms in which PGP bacteria also participate is in nitrogen fixation, phosphate solubilization, or siderophore production, all of which relate to the increase in nutrient availability in the soil [19]. Research has been carried out based on the use of PGP in agriculture to improve the yield of fruit trees, vegetables, and cereals [20] such as potato [21], wheat [22], soybean [23], apple [24], and tomato [25], among others [26,27]. However, the isolation and application of PGP from extreme conditions represents a rather unexplored scenario [28]. In this study, we isolated, identified, and characterized 71 soil bacteria from desert (Coppermine Peninsula and Lejía Lake shore), highlighting their similarities and differences attributed to their taxonomy, plant beneficial traits, and origin.

\section{Materials and Methods}

\subsection{Sample Collection and Processing}

Two extreme Chilean environments were selected for this study. The first site corresponds to Lejía Lake ( $\left.23^{\circ} 30^{\prime} \mathrm{S} 67^{\circ} 41^{\prime} 24^{\prime \prime} \mathrm{W}\right)$ in the Atacama Desert, and the second site corresponds to the Coppermine Peninsula on Robert Island, Antarctic Peninsula (62 $22^{\prime} 43^{\prime \prime}$ S 59 $49^{\prime} 21.9^{\prime \prime}$ W). From both sites, approximately $100 \mathrm{~g}$ of bulk soil samples were taken in quadruplicate at $10 \mathrm{~cm}$ depth to avoid contamination with other surfaces. Each sample was placed in sterile plastic bags and immediately stored in cold (IcePack). Samples were used for the preparation of Soil Extract Medium (SEM) as a matrix for bacterial isolation and for physical-chemical analysis.

Soil samples were taken under similar environmental conditions (during the summer after the rainy season) but in different years. Sampling in the Atacama Desert was conducted in April 2014 and that in the Antarctic Peninsula was performed in January 2019 by the ECA-55 (LV Antarctic Scientific Expedition) of INACH.

\subsection{Physical-Chemical Soil Analysis}

Temperature was recorded using a digital thermometer (Long-Stem, Thomas Traceable, Federal Government, USA) and geolocation was obtained using a Global Positioning System (GPS) equipment (64sx, Garmin, Lenexa, KS, USA). Soil $\mathrm{pH}$ was achieved by mixing soil:distilled water $(1: 1 \mathrm{p} / \mathrm{v})$ and measurement was obtained using a pH-Meter (Orion 3, Thermo Scientific, Waltham, MA, USA). 
The elemental composition of the soil was measured by Total Reflection X-ray Fluorescence Spectrometry (TXRF), using Bruker S2 PICOFOX equipment [29] following previously published protocol $[5,16]$

\subsection{Culture Conditions and Bacterial Isolation}

After field sampling, the isolation of bacteria from the collected samples was performed. Two culture media were used in both sites to obtain bacterial isolates: SEM and Luria-Bertani (LB) [30]. Briefly, SEM was prepared by mixing agar with an aqueous soil fraction (soil:distilled water, 1:1 p/v). This fraction was obtained using $80 \mathrm{~g}$ of soil mixed with $80 \mathrm{~mL}$ of distilled water. This mix was agitated for 1 hour and then decanted overnight. The soluble fraction was used to hydrate the agar $(1.5 \%)$, and finally, the mixture was autoclaved and plated. LB was prepared using $10 \mathrm{~g}$ of yeast extract, $5 \mathrm{~g}$ of peptone, $10 \mathrm{~g}$ of sodium chloride, $10 \mathrm{~g}$ of agar, and $1 \mathrm{~L}$ of distilled water. To obtain bacterial isolations, the protocol described by Mandakovic et al. [6] previously used to isolate bacteria from soil samples in the Lejía Lake was followed. Briefly, $2 \mathrm{~g}$ of soil was mixed into $2 \mathrm{~mL}$ of sterile Phosphate Buffered Saline (PBS) for $2 \mathrm{~h}$. After that time, the tubes were centrifuged for $5 \mathrm{~min}$ at $5000 \mathrm{rpm}$, and $100 \mu \mathrm{L}$ of supernatant was seeded into each of the culture media (SEM and LB) in triplicate and incubated at $30^{\circ} \mathrm{C}$. Additionally, in order to increase the possibilities of isolating specific bacteria from cold areas, samples from the Coppermine Peninsula were also incubated $16{ }^{\circ} \mathrm{C}$ for seven days in plates with SEM and LB media. Morphologically different colonies were isolated and maintained in LB medium. All strains classified as unique in the culture were stored in glycerol at $-80{ }^{\circ} \mathrm{C}$, creating a culture collection of bacteria from these extreme environments.

\subsection{Taxonomical Assignation}

The DNA of each strain was extracted using a DNeasy Blood \& Tissue Kit (QIAGEN, Hilden, Germany). The $16 \mathrm{~S}$ rDNA region was amplified using the 27F and 1492R primers. The PCR mix contained 12.5 $\mu \mathrm{L}$ of Mastermix Go Taq Promega, $8.5 \mu \mathrm{L}$ of nuclease-free water, $1 \mu \mathrm{L}$ of each primer, and $2 \mu \mathrm{L}$ of DNA. Thermal cycling followed the following steps: $10 \mathrm{~min}$ at $95^{\circ} \mathrm{C}, 30$ cycles of $95^{\circ} \mathrm{C}$ for $60 \mathrm{~s}, 58^{\circ} \mathrm{C}$ for $30 \mathrm{~s}$, and $72{ }^{\circ} \mathrm{C}$ for $60 \mathrm{~s}$, and a final extension at $72{ }^{\circ} \mathrm{C}$ for $10 \mathrm{~min}$. PCR products were kept at $4{ }^{\circ} \mathrm{C}$ until use. PCR products were visualized in $1 \%(w / v)$ agarose gel electrophoresis and sequenced (Macrogen, Inc, Geumcheon-gu, Seoul, Korea). Taxonomy was defined using the EzBioCloud (16S database), and sequences were deposited in the NCBI Genbank database. Accession numbers can be found in Table S1.

\subsection{Phylogenetic Analysis}

For the construction of the Neighbor Joining Tree, all 16S rDNA sequences obtained were trimmed according to the quality of the sequencing using CLC software (QIAGEN Bioinformatics, Hilden, Germany). Multiple cluster alignment and phylogenetic analysis were performed on MEGA software (v. 7.2) based on the neighbor binding method using a 1000 repetition bootstrap to evaluate statistical support [31].

\subsection{In Vitro Identification of Plant Growth Promoting Traits}

To biochemically classify bacteria with beneficial plant traits, five capacities were evaluated for each strain: siderophore production, auxin (AIA) production, nitrogen fixation, 1-aminocyclopropane-1-carboxylic acid (ACC) deaminase activity, and phosphate solubilization, as described in Maza et al. [30]. The production of siderophores was determined using the method described by Schwyn and Neilands [32]. Briefly, using chrome azurol agar (CAS), colonies that exhibited a yellow halo after proliferation were classified as positive for siderophore production. AIA production was evaluated by a colorimetric method. Isolates were cultured in Tryptic Soy Broth (TSB) media supplemented with $0.1 \%$ L-tryptophan as a precursor to AIA. Using Salkowski's reagent [33], the TSB media turned from yellow to violet coloration according to the concentration of AIA present in the medium, which was compared to a standard curve of indol-3-acetic acid (Merck, Burlington, MA, USA) 
ranging from $5 \mu \mathrm{g} / \mathrm{mL}$ to $180 \mu \mathrm{g} / \mathrm{mL}$. Nitrogen fixation was determined using nitrogen-free medium (NFM). Isolates were incubated for seven days and bacterial growth evidenced atmospheric nitrogen fixation [34]. ACC deaminase activity was measured by culturing bacteria with $3 \mathrm{mM}$ of ACC (Merck, Burlington, MA, USA) as the only source of nitrogen [35]; thus, bacterial growth evidenced the use of this metabolite. Finally, the phosphate solubilization capacity was determined by the presence of a halo surrounding the colonies on Pikovskayas agar medium after four days of culture [36].

\subsection{Similarity/Dissimilarity Test}

The similarity evaluation was performed using Past software (v. 4.03) through a multivariate analysis with a matrix that included each isolate, genus, and origin site. The algorithm used was the unweighted pair group method with arithmetic mean (UPGMA) and Jaccard similarity index.

\section{Results and Discussion}

\subsection{Environmental and Soil Characterization of the Study Sites}

Two Chilean desert sites were selected for this study: Lejía Lake, located in the north of Chile, specifically in the highlands of the Atacama Desert, and Coppermine Peninsula, located in the extreme-south of the country, which is part of Robert Island in the Antarctic Peninsula. To characterize the physical-chemical features of these two Chilean deserts, we performed environmental measurements during sampling and subsequently identified soluble elements in the soil through TXRF. We observed that despite being obtained from distant environments, the environmental conditions of both soil sampling sites were not significantly different in temperature, $\mathrm{pH}$, and humidity at the time of sampling (Figure 1). We expected that there would be no differences between these parameters because the sampling was performed under similar environmental conditions in both sites, after periods of constant rain, snow, and extensive cold, followed by thawing and the colonization of plant species [10,16]. However, when evaluating the chemical elements present in the soil, $\mathrm{K}, \mathrm{Ca}, \mathrm{Fe}$, and Mn were significantly higher in Lejía Lake shore soil than in the Coppermine Peninsula. These values may have a biological explanation attributed to the activity and constant fumaroles of the Lascar volcano that is located immediately above Lejía Lake. These elements, among others, have been identified and quantified through Energy-Dispersive Spectroscopy (EDS) from samples of fumaroles collected in 2012 from the Lascar Volcano [37]. On the other hand, Cu measured in soil from Lejía Lake was double the amount measured from the Coppermine Peninsula, which is an effect that could be attributed to the structure of the rock that makes up the peninsula and to mechanical weathering according to the biological processes at this site [38]. In fact, this peninsula has its name due to the evident presence of $\mathrm{Cu}$ in the rocks [39].

\subsection{Taxonomic Classification and Biochemical Characterization of Isolates}

Two culture media (SEM and LB) were used to isolate strains from Coppermine Peninsula and Lejía Lake soils (for details, see Materials and Methods). A total of 39 bacteria were isolated from Coppermine Peninsula and 32 were isolated from Lejía Lake (Table S1). To taxonomically identify all isolated bacteria, the complete $16 \mathrm{~S}$ rDNA gene was amplified and sequenced. The phylogenetic tree generated using these sequences (Figure 2) showed that the most abundant phyla in both sites corresponded to Proteobacteria and Actinobacteria, which were represented in similar quantities regardless of origin. On the other hand, Firmicutes was more represented in Lejía Lake, whereas strains related to Bacteroidetes were only isolated from the Coppermine Peninsula.

When compared to other studies carried out that isolated bacteria from soils under extreme environmental conditions in different parts of the world, our results were consistent with the isolation of mainly Proteobacteria, Firmicutes, Bacteroidetes, and Actinobacteria [40-42]. The most representative phylum corresponded to Proteobacteria at both sampling sites. A study conducted by Maza et al. [30] that analyzed the cultivable fraction of bacteria from Atacama Desert soil reported this same result, 
and a similar study developed by Gao et al. [43] through the isolation of bacteria from soil samples in arid and semi-arid sites in China described that Proteobacteria, Firmicutes, and Actinobacteria (in that order) were the most abundant phyla, while Bacteroidetes was less represented. The authors observed that this phylum seems to be more frequent in soils with better nutritional conditions; however, the phylum has also been commonly found in soils containing high concentrations of copper [44], which is consistent with the results presented above. In addition, studies carried out on other islands of the Antarctic Peninsula, specifically on Windmill Island [45] and King George Island [46], also reported that the most abundant phylum obtained from isolated bacteria corresponded to Proteobacteria.

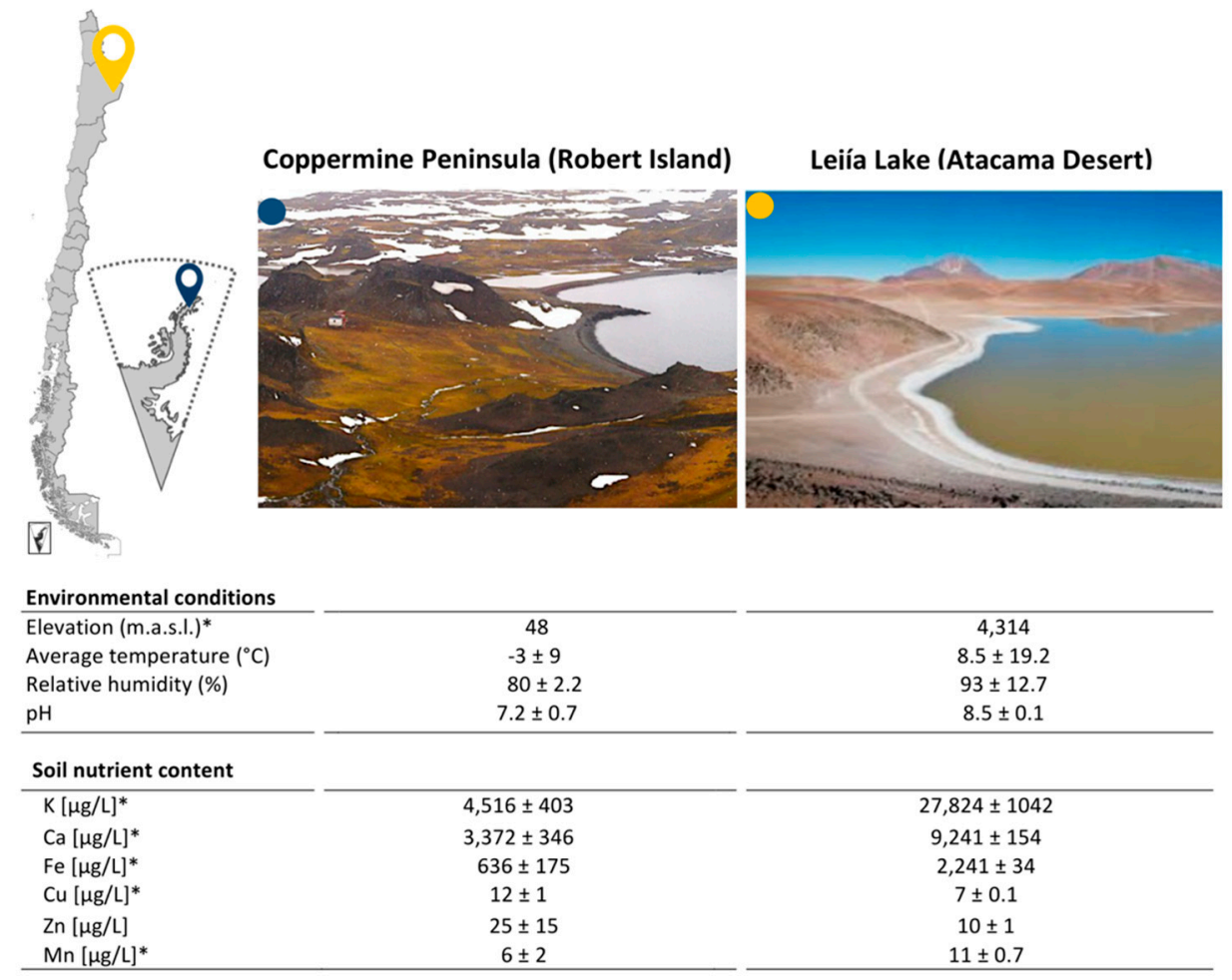

Figure 1. Extreme environments as sampling sites. Blue (Coppermine Peninsula) and yellow (Lejía Lake) icons indicate their specific locations on the map. The physicochemical parameters of both sites are described in the table. ${ }^{*} t$-test $<0.05$.

Regarding genera isolated, Pseudomonas was the most represented genus in our study, with 22 isolates from Coppermine Peninsula (56.4\%) and 11 isolates from Lejía Lake (34.4\%). We also observed the presence of less represented but specific genera in Lejía Lake, such as Stenotrophomonas (DD1), Halomonas (N5), Arthrobacter (AF3), Microbacterium (M1-B and M2-A), Rhodococcus (D4), Streptomyces (M1-A), Paenibacillus (5B and AF2), Oceanobacillus (E4), Alkalihalobacillus (E3-18 and E4-18), Bacillus (DD9, M2-B and TS1-1), Peribacillus (B1), and Mesobacillus (7C, 5D, 1C and 5C). Regarding the Coppermine Peninsula, exclusive genera found in the isolates from this site were Pusillimonas (L3D), Janthinobacterium (S6), Pseudarthrobacter (M1, M2, M3, and L2), Paeniglutamicibacter (L1D and L2D), Frondihabitans (R8), Cryobacterium (S5), Enterococcus (S1), Sporosarcina (R6D and R7D), Filibacter (R9), and Flavobacterium (R4 and S4). Romaniuk et al. [46] similarly reported that Pseudomonas was one of the most abundant genera isolated from the soil from King George Island; however, another abundant genus was Psychrobacter, from which we obtained no isolates. This may be due to the difference in culture media used in each study. As for the rest of the studies related to microorganisms isolated from Antarctic soils, they focused more on the search for fungi [8,47-49] or endophytic bacteria [50], and not on bulk soil bacteria. 


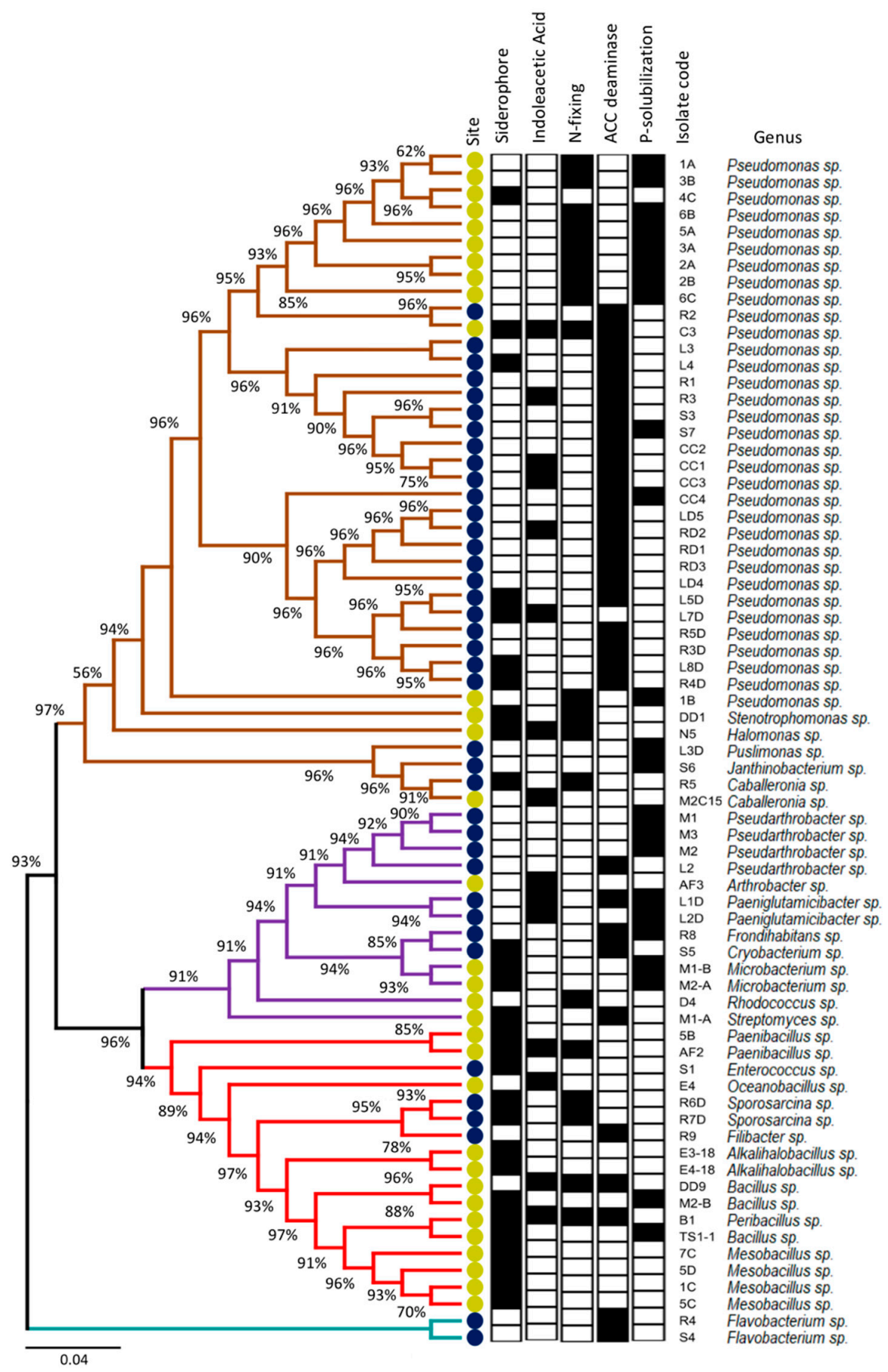

Figure 2. Phylogenetic analysis based on $16 \mathrm{~S}$ rDNA gene sequences and characterization of plant beneficial traits of soil bacterial isolates. The colored branches represent different phyla: Proteobacteria (brown), Actinobacteria (purple), Firmicutes (red), and Bacteroidetes (blue). The colored circles represent different sampling sites: Lejía Lake (yellow) and Coppermine Peninsula (blue). Positive (black box) and negative plant beneficial traits (white box). Bar, 0.04 substitutions per position.

Two bacteria of the genus Pseudomonas (isolate C3) and Peribacillus (isolate B1) were isolated from the Lejía Lake, which had four positive PGP capacities, while in the Coppermine Peninsula, the soil isolate with the highest number of PGP capacities corresponded to the genus Paeniglutamicibacter (isolate L1D) with three PGP capacities out of the five evaluated. In general, Antarctic strains had less PGP traits than Lejía Lake isolates. Most of the Coppermine Peninsula strains possessed ACC deaminase activity, while the strains from Lejía Lake were more heterogeneous in terms of their 
PGP capabilities. The fact that a high percentage of bacteria present in the soil had at least one PGP capacity despite being isolated from bulk soil is consistent with a study carried out in Namibia Desert, in which a higher percentage of bacteria with PGP activities was isolated from bulk soil rather than from rhizospheres, proposing these strains as potential biofertilizers for arid areas [51]. The genus Sporosarcine was only represented in the Coppermine Peninsula, presenting two of the five PGP capacities evaluated. In this context, Yadav et al. [52] described a series of bacteria isolated from the Himalayan desert, declaring Sporosarcine to be a potent PGP candidate to use in low-temperature crops. Additionally, Halomonas genus was part of the set of bacteria isolated and characterized as plant beneficial traits from Lejía Lake. This genus was also isolated and characterized in the desert of southern Tunisia, and the genus was proposed as a potential plant growth promoter under salinity and drought conditions [53]. Other authors [54,55] have suggested that PGP bacteria isolated from extreme environments can be used as inoculants under similar conditions from where they were isolated; thus, bacteria isolated from a cold desert may be used to counteract cold stress, while bacteria isolated from arid conditions can be used to reduce drought effects [56].

\subsection{Similarity/Dissimilarity of Soil Isolates}

To evaluate the similarity among all the isolates, we calculated the Jaccard distance considering the origin of the sample, their taxonomic identification, and their PGP capacities. Figure 3 shows that each strain is specifically grouped according to the place of origin and its PGP capabilities. Phyla and genera are rearranged and randomly distributed in the dendrogram. The group with the most isolates corresponded to the strains that possessed ACC deaminase capacity only, all belonging to Coppermine Peninsula soil. The second most represented group contained only bacteria isolated from Lejía Lake soil, which had the PGP characteristics of nitrogen fixation and phosphate solubilization.

We expected that the bacteria isolated in the two sampling sites would have equivalent PGP capabilities, considering that both deserts have similar environmental conditions and also share taxonomic groups. Therefore, we estimated that when performing a multivariate test, the main factors that would cluster together would be taxonomy and plant beneficial traits, regardless of the origin of the sample. Nevertheless, at the time of conducting the similarity test using the Jaccard index, taxonomy was irrelevant, and isolates were grouped by their PGP capabilities, which also coincided with their isolation site. This could be explained by the fact that despite having similar environmental conditions during sampling, sites at other times of the year are completely different, which could impact site-specific microbiological adaptations and PGP characteristics. For example, for most of the year, the Coppermine Peninsula is covered with snow [10], while in Lejía Lake, it only snows for a few weeks a year and only in winter [30].

Although further investigations should be done, including the addition of more isolates, we think that these differences could be due to nutritional factors (including $\mathrm{K}, \mathrm{Ca}, \mathrm{Fe}, \mathrm{Cu}$, and $\mathrm{Mn}$ ) (Figure 1), suggesting a tight connection between the PGP capacities of bacterial isolates and the environment [5]. However, there are differences among the plant beneficial traits in bacterial isolates located in different regions of the world, making it difficult to separate historic and phylogeographic effects from local features of soil. Antarctica is considered one of the most extreme sites in the world, where different conditions and environments not found elsewhere can be studied [8]. Here, the colonization of species and life is at its limit, not only because of the cold and low availability of water, but also due to the constant cycles of freezing and thawing, continuous strong winds, and high UV radiation [9]. Additionally, effects produced by deglaciation and climate change have allowed the colonization of plant species in soils that were previously covered by ice or snow [6,7]. We believe that this has also produced an effect on the microbiological composition of the soil. On the other hand, the Atacama Desert is considered a cold and arid desert [14], but it presents important temperature fluctuations between day and night [5], which are even more significant in the highlands, where Lejía Lake is located. It is also possible to observe vegetation of different herbaceous species at an altitude of between 4000 and 4500 meters above sea level, which is attributed to the higher levels of precipitation 
and humidity in the area. Lower altitudes correspond to the beginning of the absolute desert [15]. Studying desert soils from these two sites in relation to the metabolic capacities of microorganisms could help us understand how they sustain life in different extreme conditions, which may also impact new or better biotechnological tools [17].

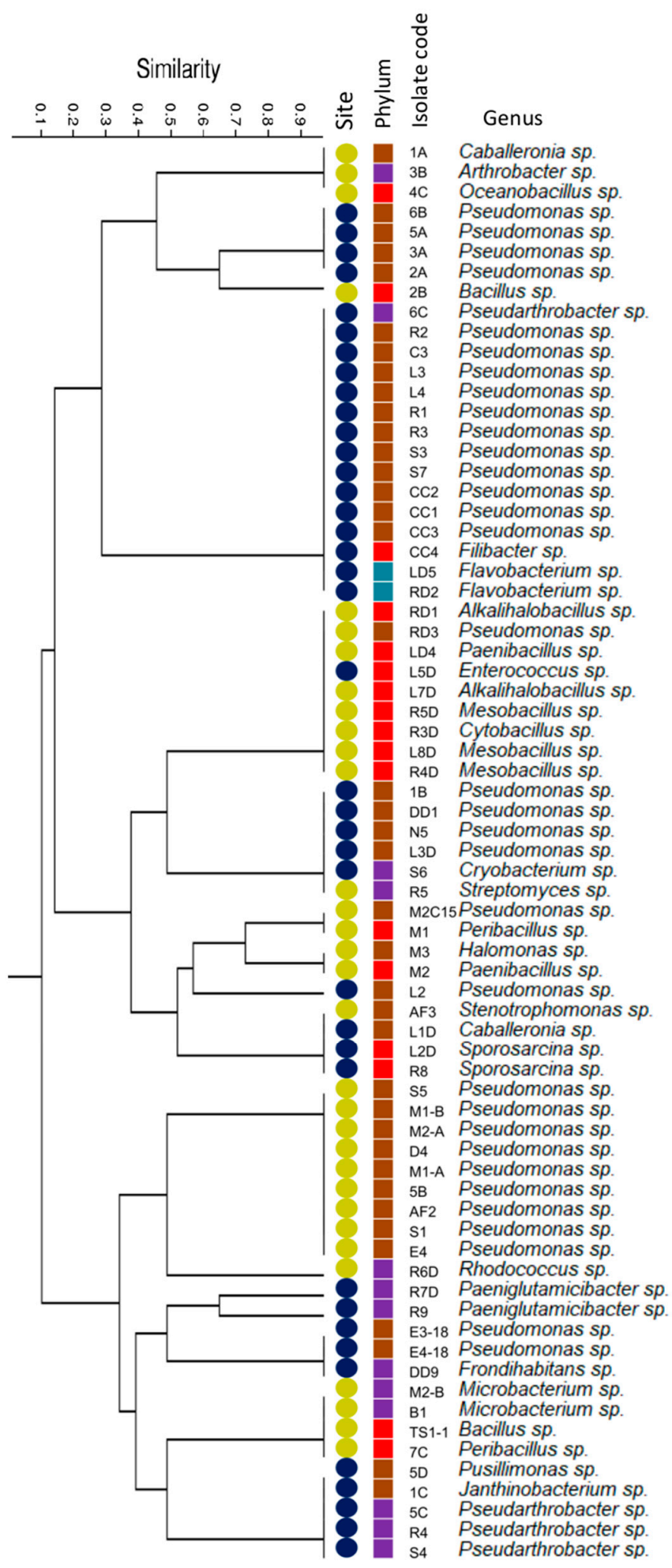

Figure 3. Similarity analysis through the Jaccard index. The colors of the circles represent different sampling sites: (yellow) Lejía Lake and (blue) Coppermine Peninsula. The colored box represents different Phyla. Proteobacteria (brown), Actinobacteria (purple), Firmicutes (red), and Bacteroidetes (light blue). 
Finally, Jorquera et al. [1] declare that species present in extreme environments are modifying their distribution and abundance due to climate change, and as a result, the microbial communities that inhabit these places represent a biotechnological tool with the capacity to solve current problems in agriculture, focused on improving the tolerance of crops in drought, floods, heat stress, and saline levels, among others. Therefore, bacteria with plant growth capacities obtained from these extreme desert environments are an unexplored source of novel biological resources, with enormous potential for biotechnology and its industry.

Extreme environments have been studied in various settings due to the interesting capacities developed by the different species that inhabit them [1]. In particular, it has been shown that bacteria are the first organisms to colonize these environments through metabolic adaptations [57], which increase the possibility of colonization by species that act as biological stabilizers (fungi, lichens, and mosses), which could also be an important niche for seed germination or the establishment of plant species [58]. Generally, bacteria with PGP capabilities have been isolated from crops with agronomic interest under stable environmental conditions [59] in order to improve crop yield [60,61], while PGP bacteria isolated from extreme environments are relatively unexplored [62]. In an era of climate change, the identification, isolation, and characterization of bacteria with PGP properties that come from extreme environments that may favor plant growth under abiotic stress conditions represent excellent and novel biotechnological tools to fight future harsh conditions [30,63]. Furthermore, soil for vegetable cultivation is increasingly limited, which is a problem for world food security; therefore, the use of these bacteria involves increasing the availability of nutrients in the soil and improving the tolerance, productivity, and yield of plants of agronomic interest [64-66].

The ability of bacteria to adapt and survive in cold environments attracts many researchers interested in solving this adaptive attribute and also in developing new or better biotechnological tools. Bacteria of the genus Arthrobacter, Bacillus, Janthinobacterium, Pseudomonas, and Sporosarcine, among others, have been described as having different mechanisms associated with cold stress tolerance, such as cold acclimation proteins (Caps) and antifreezing proteins (AFPs) that protect the specific cytoplasmic and extracellular components involved in cold adaptation [55]. In addition, a study by Zubair et al. [67] showed that the Bacillus genus presents mechanisms of response to cold stress through the formation of biofilms, the production of Reactive Oxygen Species (ROS), and also through the expression of the acdS gene, which is related to the ACC deaminase activity committed to the PGP capacity.

Supplementary Materials: The following are available online at http://www.mdpi.com/2076-2607/8/8/1213/s1, Table S1. Taxonomic and molecular information of bacteria isolated from desert soils.

Author Contributions: A.G. conceived the study, designed the experiments, analyzed the results, and wrote the first draft. A.G. and D.M. performed the sampling and isolated the bacteria. M.G. supervised the study. M.G. and D.M. funded the study, reviewed and edited the manuscript draft. All authors have read and agreed to the published version of the manuscript.

Funding: This study was funded by the project FONDAP-CRG 15090007, Fondecyt 1201278 and Fondecyt 3170523.

Acknowledgments: The authors wish to acknowledge Andrés Marcoleta for the invitation to participate in the Antarctic Scientific Expedition (ECA-55) organized by the Chilean Antarctic Institute (INACH).

Conflicts of Interest: The authors declare no conflicts of interest.

\section{References}

1. Jorquera, M.; Graether, S.P.; Maruyama, F. Editorial: Bioprospecting and Biotechnology of Extremophiles. Front. Bioeng. Biotechnol. 2019, 7, 204. [CrossRef] [PubMed]

2. Orellana, R.; Macaya, C.; Bravo, G.; Dorochesi, F.; Cumsille, A.; Valencia, R.; Rojas, C.; Seeger, M. Living at the Frontiers of Life: Extremophiles in Chile and Their Potential for Bioremediation. Front. Microbiol. 2018, 9 , 2309. [CrossRef] [PubMed]

3. Li, S.-J.; Hua, Z.-S.; Huang, L.-N.; Li, J.; Shi, S.-H.; Chen, L.-X.; Kuang, J.-L.; Liu, J.; Hu, M.; Shu, W.-S. Microbial communities evolve faster in extreme environments. Sci. Rep. 2014, 4, 06205. [CrossRef] [PubMed] 
4. Wierzchos, J.; Casero, M.C.; Artieda, O.; Ascaso, C. Endolithic microbial habitats as refuges for life in polyextreme environment of the Atacama Desert. Curr. Opin. Microbiol. 2018, 43, 124-131. [CrossRef]

5. Mandakovic, D.; Maldonado, J.; Pulgar, R.; Cabrera, P.; Gaete, A.; Urtuvia, V.; Seeger, M.; Cambiazo, V.; González, M. Microbiome analysis and bacterial isolation from Lejía Lake soil in Atacama Desert. Extremophiles 2018, 22, 665-673. [CrossRef]

6. Körner, C. Coldest places on earth with angiosperm plant life. Alp. Bot. 2011, 121, 11-22. [CrossRef]

7. Friedman, C.L.; Selin, N.E. PCBs in the Arctic atmosphere: Determining important driving forces using a global atmospheric transport model. Atmospheric Chem. Phys. Discuss. 2015, 15, 3433-3448. [CrossRef]

8. Durán, P.; Barra, P.J.; Jorquera, M.A.; Viscardi, S.; Fernandez, C.; Paz, C.; Mora, M.D.L.L.; Bol, R. Occurrence of Soil Fungi in Antarctic Pristine Environments. Front. Bioeng. Biotechnol. 2019, 7, 28. [CrossRef]

9. Ruisi, S.; Barreca, D.; Selbmann, L.; Zucconi, L.; Onofri, S. Fungi in Antarctica. Life Extrem. Environ. 2007, 6, 127-141.

10. Torres-Mellado, G.A.; Jaña, R.; Casanova-Katny, M.A. Antarctic hairgrass expansion in the South Shetland archipelago and Antarctic Peninsula revisited. Polar Boil. 2011, 34, 1679. [CrossRef]

11. Benavent-González, A.; Delgado-Baquerizo, M.; Fernández-Brun, L.; Singh, B.K.; Maestre, F.T.; Sancho, L.G. Identity of plant, lichen and moss species connects with microbial abundance and soil functioning in maritime Antarctica. Plant Soil 2018, 429, 35-52. [CrossRef] [PubMed]

12. Thomazini, A.; Francelino, M.R.; Pereira, A.B.; Schünemann, A.L.; Mendonça, E.D.S.; Michel, R.F.M.; Schaefer, C.E.G.R. The current response of soil thermal regime and carbon exchange of a paraglacial coastal land system in maritime Antarctica. Land Degrad. Dev. 2019, 31, 655-666. [CrossRef]

13. Bravo, L.A. Characterization of antifreeze activity in Antarctic plants. J. Exp. Bot. 2005, 56, 1189-1196. [CrossRef] [PubMed]

14. Díaz, F.P.; Frugone, M.; Gutiérrez, R.A.; Latorre, C. Nitrogen cycling in an extreme hyperarid environment inferred from $\delta 15 \mathrm{~N}$ analyses of plants, soils and herbivore diet. Sci. Rep. 2016, 6, 1-11. [CrossRef]

15. Díaz, F.P.; Latorre, C.; Carrasco-Puga, G.; Wood, J.R.; Wilmshurst, J.; Soto, D.C.; Cole, T.L.; Gutiérrez, R.A. Multiscale climate change impacts on plant diversity in the Atacama Desert. Glob. Chang. Boil. 2019, 25, 1733-1745. [CrossRef]

16. Fernández-Gómez, B.; Maldonado, J.; Mandakovic, D.; Gaete, A.; Gutiérrez, R.A.; Maass, A.; Cambiazo, V.; González, M. Bacterial communities associated to Chilean altiplanic native plants from the Andean grasslands soils. Sci. Rep. 2019, 9, 1-12. [CrossRef]

17. Bull, A.T.; Asenjo, J. Microbiology of hyper-arid environments: Recent insights from the Atacama Desert, Chile. Antonie van Leeuwenhoek 2013, 103, 1173-1179. [CrossRef]

18. Vejan, P.; Abdullah, R.; Tumirah, K.; Ismail, S.; Boyce, A.N. Role of Plant Growth Promoting Rhizobacteria in Agricultural Sustainability-A Review. Molecules 2016, 21, 573. [CrossRef]

19. Bashan, Y.; De-Bashan, L.E. Plant growth-promoting. Encycl. Soils Environ. 2005, 1, 103-115.

20. Jorquera, M.; Inostroza, N.G.; Lagos, L.M.; Barra, P.J.; Marileo, L.G.; Rilling, J.I.; Campos, D.C.; Crowley, D.; Richardson, A.E.; Mora, M.L. Bacterial community structure and detection of putative plant growth-promoting rhizobacteria associated with plants grown in Chilean agro-ecosystems and undisturbed ecosystems. Boil. Fertil. Soils 2014, 50, 1141-1153. [CrossRef]

21. Naqqash, T.; Hameed, S.; Imran, A.; Hanif, M.K.; Majeed, A.; Van Elsas, J.D. Differential Response of Potato Toward Inoculation with Taxonomically Diverse Plant Growth Promoting Rhizobacteria. Front. Plant Sci. 2016, 7, 144. [CrossRef] [PubMed]

22. Bharti, N.; Pandey, S.S.; Barnawal, D.; Patel, V.K.; Kalra, A. Plant growth promoting rhizobacteria Dietzia natronolimnaea modulates the expression of stress responsive genes providing protection of wheat from salinity stress. Sci. Rep. 2016, 6, 1-16. [CrossRef] [PubMed]

23. Husen, E.; Wahyudi, A.T.; Suwanto, A.; Saraswati, R. Soybean seedling root growth promotion by 1-aminocyclopropane-1-carboxylate deaminase-producing pseudomonads. Indones. J. Agric. Sci. 2016, 10, 19-25. [CrossRef]

24. Karlidag, H.; Eşitken, A.; Turan, M.; Sahin, F. Effects of root inoculation of plant growth promoting rhizobacteria (PGPR) on yield, growth and nutrient element contents of leaves of apple. Sci. Hortic. 2007, 114, 16-20. [CrossRef] 
25. Ibort, P.; Molina, S.; Lozano, J.M.R.; Aroca, R. Molecular Insights into the Involvement of a Never Ripe Receptor in the Interaction Between Two Beneficial Soil Bacteria and Tomato Plants Under Well-Watered and Drought Conditions. Mol. Plant-Microbe Interactions 2018, 31, 633-650. [CrossRef] [PubMed]

26. Zhao, J.; Zhao, X.; Wang, J.; Gong, Q.; Zhang, X.; Zhang, G. Isolation, Identification and Characterization of Endophytic Bacterium Rhizobium oryzihabitans sp. nov., from Rice Root with Biotechnological Potential in Agriculture. Microorganisms 2020, 8, 608. [CrossRef]

27. Gu, Y.; Wang, J.; Xia, Z.Y.; Wei, H.-L. Characterization of a Versatile Plant Growth-Promoting Rhizobacterium Pseudomonas mediterranea Strain S58. Microorganisms 2020, 8, 334. [CrossRef]

28. Subramanian, P.; Kim, K.; Krishnamoorthy, R.; Mageswari, A.; Selvakumar, G.; Sa, T. Cold Stress Tolerance in Psychrotolerant Soil Bacteria and Their Conferred Chilling Resistance in Tomato (Solanum lycopersicum Mill.) under Low Temperatures. PLoS ONE 2016, 11, e0161592. [CrossRef]

29. De La Calle, I.; Costas, M.; Cabaleiro, N.; Lavilla, I.; Bendicho, C. Fast method for multielemental analysis of plants and discrimination according to the anatomical part by total reflection X-ray fluorescence spectrometry. Food Chem. 2013, 138, 234-241. [CrossRef]

30. Maza, F.; Maldonado, J.; Vásquez-Dean, J.; Mandakovic, D.; Gaete, A.; Cambiazo, V.; González, M. Soil Bacterial Communities from the Chilean Andean Highlands: Taxonomic Composition and Culturability. Front. Bioeng. Biotechnol. 2019, 7, 10. [CrossRef]

31. Mandakovic, D.; Cintolesi, Á.; Maldonado, J.; Mendoza, S.N.; Aïte, M.; Gaete, A.; Saitua, F.; Allende, M.; Cambiazo, V.; Siegel, A.; et al. Genome-scale metabolic models of Microbacterium species isolated from a high altitude desert environment. Sci. Rep. 2020, 10, 1-13. [CrossRef] [PubMed]

32. Schwyn, B.; Neilands, J. Universal chemical assay for the detection and determination of siderophores. Anal. Biochem. 1987, 160, 47-56. [CrossRef]

33. Mohite, B. Isolation and characterization of indole acetic acid (IAA) producing bacteria from rhizospheric soil and its effect on plant growth. J. Soil Sci. Plant Nutr. 2013, 13, 638-649. [CrossRef]

34. Grobelak, A.; Napora, A.; Kacprzak, M. Using plant growth-promoting rhizobacteria (PGPR) to improve plant growth. Ecol. Eng. 2015, 84, 22-28. [CrossRef]

35. Penrose, D.M.; Glick, B.R. Methods for isolating and characterizing ACC deaminase-containing plant growth-promoting rhizobacteria. Physiol. Plant. 2003, 118, 10-15. [CrossRef]

36. Ahmad, F.; Ahmad, I.; Khan, M. Screening of free-living rhizospheric bacteria for their multiple plant growth promoting activities. Microbiol. Res. 2008, 163, 173-181. [CrossRef]

37. Sainlot, N.; Vlastelic, I.; Moune, S.; Rose-Koga, E.; Schiavi, F.; Valade, S.; Aguilera, F. Uptake of gaseous thallium, tellurium, vanadium and molybdenum into anhydrous alum, Lascar volcano fumaroles, Chile. Geochim. et Cosmochim. Acta 2020, 275, 64-82. [CrossRef]

38. Malandrino, M.; Abollino, O.; Buoso, S.; Casalino, C.E.; Gasparon, M.; Giacomino, A.; La Gioia, C.; Mentasti, E. Geochemical characterisation of Antarctic soils and lacustrine sediments from Terra Nova Bay. Microchem. J. 2009, 92, 21-31. [CrossRef]

39. Paula, M.D. Gênese e classificação de solos na península Coppermine (ilha Robert) e ilha Barrientos, Antártica Marítima; Universidade Federal de Viçosa: Minas Gerais, Brazil, 2015.

40. An, S.; Couteau, C.; Luo, F.; Neveu, J.; Dubow, M.S. Bacterial Diversity of Surface Sand Samples from the Gobi and Taklamaken Deserts. Microb. Ecol. 2013, 66, 850-860. [CrossRef]

41. Puspitasari, F.; Maki, T.; Shi, G.; Bin, C.; Kobayashi, F.; Hasegawa, H.; Iwasaka, Y. Phylogenetic analysis of bacterial species compositions in sand dunes and dust aerosol in an Asian dust source area, the Taklimakan Desert. Air Qual. Atmosphere Heal. 2015, 9, 631-644. [CrossRef]

42. Majid, S.A.; Graw, M.F.; Chatziefthimiou, A.; Nguyen, H.; Richer, R.; Louge, M.Y.; Sultan, A.A.; Schloss, P.D.; Hay, A.G. Microbial Characterization of Qatari Barchan Sand Dunes. PLoS ONE 2016, 11, e0161836.

43. Gao, J.; Luo, Y.; Wei, Y.; Huang, Y.; Zhang, H.; He, W.; Sheng, H.; An, L.-Z. Screening of plant growth promoting bacteria (PGPB) from rhizosphere and bulk soil of Caragana microphylla in different habitats and their effects on the growth of Arabidopsis seedlings. Biotechnol. Biotechnol. Equip. 2019, 33, 921-930. [CrossRef]

44. Kou, S.; Vincent, G.; Gonzalez, E.; Pitre, F.E.; Labrecque, M.; Brereton, N.J.B. The Response of a 16S Ribosomal RNA Gene Fragment Amplified Community to Lead, Zinc, and Copper Pollution in a Shanghai Field Trial. Front. Microbiol. 2018, 9, 366. [CrossRef] [PubMed] 
45. Chong, C.-W.; Silvaraj, S.; Supramaniam, Y.; Snape, I.; Tan, I.K.P. Effect of temperature on bacterial community in petroleum hydrocarbon-contaminated and uncontaminated Antarctic soil. Polar Boil. 2018, 41, 1763-1775. [CrossRef]

46. Romaniuk, K.; Ciok, A.; Decewicz, P.; Uhrynowski, W.; Budzik, K.; Nieckarz, M.; Pawlowska, J.; Zdanowski, M.K.; Bartosik, D.; Dziewit, L. Insight into heavy metal resistome of soil psychrotolerant bacteria originating from King George Island (Antarctica). Polar Boil. 2018, 41, 1319-1333. [CrossRef]

47. De Menezes, G.C.A.; Godinho, V.M.; Porto, B.A.; Gonçalves, V.N.; Rosa, L.H. Antarctomyces pellizariae sp. nov., a new, endemic, blue, snow resident psychrophilic ascomycete fungus from Antarctica. Extremophiles 2016, 21, 259-269. [CrossRef]

48. Troncoso, E.; Barahona, S.; Carrasco, M.; Villarreal, P.; Alcaíno, J.; Cifuentes, V.; Baeza, M. Identification and characterization of yeasts isolated from the South Shetland Islands and the Antarctic Peninsula. Polar Boil. 2016, 40, 649-658. [CrossRef]

49. Gomes, E.C.Q.; Figueredo, H.M.; De Oliveira, F.S.; Schaefer, C.E.G.R.; Michel, R.F.; Rosa, C.A.; Rosa, L.H. Fungi Present in Soils of Antarctica. In Fungi of Antarctica; Springer: Cham, Switzerland, 2019; pp. $43-67$.

50. Zhang, Q.; Acuña, J.J.; Inostroza, N.G.; Mora, M.L.; Radic, S.; Sadowsky, M.J.; Jorquera, M. Endophytic Bacterial Communities Associated with Roots and Leaves of Plants Growing in Chilean Extreme Environments. Sci. Rep. 2019, 9, 1-12. [CrossRef]

51. Kandjimi, O.S.; Uzabakiriho, J.; Chimwamurombe, P.M. Isolation and characterization of culturable bacteria from bulk soil samples and the rhizosphere of arid-adapted Tylosema esculentum (Burchell). A. Schreiber (Marama bean) in Namibia. Afr. J. Biotechnol. 2015, 14, 944-952.

52. Yadav, A.N.; Sachan, S.G.; Verma, P.; Saxena, A.K. Bioprospecting of plant growth promoting psychrotrophic Bacilli from the cold desert of north western Indian Himalayas. Indian J. Exp. Boil. 2016, 54, 142-150.

53. Mapelli, F.; Marasco, R.; Rolli, E.; Barbato, M.; Chérif, H.; Guesmi, A.; Ouzari, I.; Daffonchio, D.; Borin, S. Potential for Plant Growth Promotion of Rhizobacteria Associated with Salicornia Growing in Tunisian Hypersaline Soils. BioMed Res. Int. 2013, 2013, 1-13. [CrossRef] [PubMed]

54. Tistechok, S.; Skvortsova, M.; Luzhetskyy, A.; Fedorenko, V.; Parnikoza, I.; Gromyko, O. Antagonistic and plant growth promoting properties of actinomycetes from rhizosphere Deschampsia antarctica È. Desv. (Galindez Island, Antarctica). УкраїнськийАнтарктичний Журнал 2019, 1, 1727-7485. [CrossRef]

55. Yadav, A.N.; Yadav, N.; Sachan, S.G.; Saxena, A.K. Biodiversity of psychrotrophic microbes and their biotechnological applications. J. Appl. Biol. Biotechnol. 2019, 7, 99-108.

56. Govindasamy, V.; George, P.; Kumar, M.; Aher, L.; Raina, S.K.; Rane, J.; Annapurna, K.; Minhas, P.S. Multi-trait PGP rhizobacterial endophytes alleviate drought stress in a senescent genotype of sorghum [Sorghum bicolor (L.) Moench]. 3 Biotech 2019, 10, 13. [CrossRef]

57. Borin, S.; Ventura, S.; Tambone, F.; Mapelli, F.; Schubotz, F.; Brusetti, L.; Scaglia, B.; D' Acqui, L.P.; Solheim, B.; Turicchia, S.; et al. Rock weathering creates oases of life in a High Arctic desert. Environ. Microbiol. 2010, 12, 293-303. [CrossRef]

58. Soussi, A.; Ferjani, R.; Marasco, R.; Guesmi, A.; Cherif, H.; Rolli, E.; Mapelli, F.; Ouzari, H.I.; Daffonchio, D.; Cherif, A. Plant-associated microbiomes in arid lands: Diversity, ecology and biotechnological potential. Plant Soil 2015, 405, 357-370. [CrossRef]

59. Guo, H.-B.; He, S.-W.; Wang, X.; Thin, K.-K.; Wei, H.-L.; Zhang, X. Bacillus telluris sp. nov. Isolated from Greenhouse Soil in Beijing, China. Microorganisms 2020, 8, 702. [CrossRef]

60. Aarab, S.; Ollero, F.J.; Megías, M.; Laglaoui, A.; Bakkali, M.; Arakrak, A. Isolation and screening of bacteria from rhizospheric soils of rice fields in Northwestern Morocco for different plant growth promotion (PGP) activities: An in vitro study. Int. J. Curr. Microbiol. App. Sci. 2015, 4, 260-269.

61. Chennappa, G.; Naik, M.K.; Adkar-Purushothama, C.R.; Amaresh, Y.S.; Sreenivasa, M.Y. PGP potential, abiotic stress tolerance and antifungal activity of Azotobacter strains isolated from paddy soils. Indian J. Exp. Boil. 2016, 54, 322-331.

62. Cid, F.P.; Inostroza, N.G.; Graether, S.P.; Bravo, L.A.; Jorquera, M. Bacterial community structures and ice recrystallization inhibition activity of bacteria isolated from the phyllosphere of the Antarctic vascular plant Deschampsia antarctica. Polar Boil. 2016, 40, 1319-1331. [CrossRef]

63. Yadav, A.N. Plant Growth Promoting Bacteria: Biodiversity and Multifunctional Attributes for Sustainable Agriculture. Adv. Biotechnol. Microbiol. 2017, 5, 1-16. 
64. Lakshmanan, V.; Ray, P.; Craven, K.D. Toward a resilient, functional microbiome: Drought tolerancealleviating microbes for sustainable agriculture. In Plant Stress Tolerance; Humana Press: New York, NY, USA, 2017; pp. 69-84.

65. Hussain, S.S.; Mehnaz, S.; Siddique, K.H.M. Harnessing the Plant Microbiome for Improved Abiotic Stress Tolerance. In Advances in Plant Microbiome and Sustainable Agriculture; Springer: Singapore, 2018; pp. 21-43.

66. Ahmad, M.; Nadeem, S.M.; Zahir, Z.A. Plant-Microbiome Interactions in Agroecosystem: An Application. In Microbiome in Plant Health and Disease; Springer: Singapore, 2019; pp. 251-291.

67. Zubair, M.; Hanif, A.; Farzand, A.; Majid, T.; Khan, A.R.; Suleman, M.; Ayaz, M.; Gao, X.; Khan; Ayaz; et al. Genetic Screening and Expression Analysis of Psychrophilic Bacillus spp. Reveal Their Potential to Alleviate Cold Stress and Modulate Phytohormones in Wheat. Microorganisms 2019, 7, 337. [CrossRef]

(C) 2020 by the authors. Licensee MDPI, Basel, Switzerland. This article is an open access article distributed under the terms and conditions of the Creative Commons Attribution (CC BY) license (http://creativecommons.org/licenses/by/4.0/). 